\title{
Knowing what we count: a comment on Guo
}

\author{
Petr Pyšek \\ Institute of Botany, Department of Invasion Ecology, Academy of Sciences of the Czech Republic, CZ-252 43 \\ Prühonice, Czech Republic \& Department of Ecology, Faculty of Science, Charles University Prague, Viničná \\ 7, CZ-128 01 Prague, Czech Republic \\ Corresponding author: Petr Pyšek (pysek@ibot.cas.cz)
}

Academic editor: IngolfKühn | Received 28 August 2011 | Accepted 8 September 2011 | Published 5 October 2011

Citation: Pyšek P (2011) Knowing what we count: a comment on Guo. NeoBiota 10: 81-88. doi: 10.3897/ neobiota. 10.1976

Guo (2011) points to problems arising from different approaches to estimating the proportions of floras that are native or alien, specifically those across and within various regions. This results in inconsistency of numbers reported from internal administrative units by underestimating the numbers of species that are alien to the region and overestimating native species richness. Resulting species numbers and proportions for smaller units within large countries, or whole continents, can be seriously biased if only species alien to the larger unit as a whole are considered alien, while all other species are considered native.

\section{Alien species databases for large regions need to be built bottom-up}

This issue has been dealt with in detail in some invasion biology literature from other regions of the world, a fact that is not acknowledged in Guo (2011). Moreover, even for the US it is not true that previously published plant richness data for each state were always based on species either native or exotic to the entire country, as stated by Guo (2011). The issue has been thoroughly considered in some US state floras, such as California, where species with their origin in other parts of the US were consistently counted as aliens (Rejmánek et al. 1991; Rejmánek and Randall 1994). The analysis by these authors was based on detailed data from the Jepson Manual (Hickman 1993) which represents an excellent regional dataset collated through intensive historical research. However, this is not only true for California; across the US the nativity concept

Copyright Petr Pyšek. This is an open access article distributed under the terms of the Creative Commons Attribution License, which permits unrestricted use, distribution, and reproduction in any medium, provided the original author and source are credited. 
has been consistently applied at the regional level. Rejmánek and Randall (1994, their Table 2) give the numbers of native and naturalized alien plant species for 37 regions in North America and Hawaii, both at the state level or smaller. They derived the lists from regional or state botanical floras and carefully re-checked each species in terms of their status and origin. For North America there is good coverage of the territory generally; Palmer (2005) reports data from 1870 floras, ranging in size from local checklists to states, provinces and countries. A survey conducted to determine what data currently exists for alien species in the US identified 319 datasets. These datasets ranged from county to national and global scales, with most of them related to plants (Crall et al. 2006). Therefore the data from which native vs alien status can be correctly assessed does exist, it just needs to be searched for in appropriate sources.

The above indicates that the problem may be more political/management related, rather than scientific, i.e. rather related to large databases covering the whole country and built for pratical purposes, such as USDA and NRCS, referred to by Guo (2011). Despite biases in the literature on biological invasions, resulting from varying research intensity and regional differences in the level of knowledge (Pyšek et al. 2008), for many regions with a botanical tradition the data can be found in basic botanical works. Floras and checklists of individual regions are generally more precise, for obvious reasons, than if regional information is derived from continental-scale summary floral works or checklists, where the level of inaccuracy, especially when it comes to origin of species and treatment of aliens, can be quite high (Pyšek 2003). The difference between a database of alien species built from the bottom-up and country data downscaled from a continental-wide account, can be illustrated by a comparison of European situation as reported by Lambdon et al. (2008) and Weber (1997). Generally, the bottom-up approach of building alien species databases is scientifically more rigorous and provides more exact information than that resulting from application of nationwide or continental checklists to regional situations.

\section{Illustrating the magnitude of bias on European data}

European data (based on the DAISIE project; DAISIE 2009) provide additional and more systematic illustration of the problem pointed by Guo (2011), as well as of its magnitude. The treatment of European alien flora was based on compiling regional checklists and accurately distinguishing between alien species with their native range entirely outside the continental boundaries (termed "alien to" Europe) and alien species of European origin, including those that are native in a part of Europe but alien to another. Both subgroups together formed the "alien in" Europe category, comprising species alien across all regions (Lambdon et al. 2008; Pyšek et al. 2009b). This approach, previously used also by Weber (1997) in his analysis of the continental flora based on Flora Europaea, represents a rare case in studies on biological invasions when administrative boundaries are an advantage because the history and tradition of botan- 
ical research relates to individual nations. Therefore, country-based research is ideally suited to reliably distinguish native and alien species at this scale.

On the continent as a whole there are 3749 naturalized (sensu Richardson et al. 2000; Blackburn et al. 2011) aliens in Europe, of which 1780 are alien to Europe. Therefore $47 \%$ of alien species are of extra-European origin (Lambdon et al. 2008). To estimate total alien species richness and its contribution to the total plant diversity in Europe, only species with extra-European origin are relevant. The 1780 naturalized aliens in this group add to 10,928 native species (as given in Winter et al. 2009), resulting in $14 \%$ of plant species in Europe being alien.

At the scale of individual countries, for example considering incorrectly only those aliens with their region of origin entirely outside of Europe would move 522 of the neophytes (alien species introduced since the beginning of the 16th century) in the Czech Republic (49.9\% of the total number of neophytes) into the "native" category. This would reduce the number of neophytes recorded from 1046 to 524, and their proportional contribution to the country's entire flora from $25.3 \%$ to $12.7 \%$ (based on data in Pyšek et al. 2002). The difference between figures obtained by applying the two approaches is of similar magnitude for other countries in Europe (www.europealiens.org).

\section{Reconciling ecological and biogeographical approaches}

The problem is essentially one of scale. There is no specific scale at which invasions should be studied, and the patterns and processes found by researchers differ according to the grain of the study (e.g., Hamilton et al. 2005; Pyšek and Hulme 2005). As pointed by Guo (2011), the concept of nativity/origin status depends on the size of the unit examined. It needs to be emphasized that with an increase in scale, the approach changes from an ecological one (with focus on colonization and evaluation of nativity at the level of a community or habitat), to a biogeographical one (addressing the issue of origin at the level of a region, country or continent). This reflects the differences in perceiving new species through ecological, biogeographical and anthropocentric approaches, and also in the definitions used (e.g. colonizers, invaders and weeds; Rejmánek 2000). As the scale of study decreases, the boundary between the concepts of "native" and "alien" becomes more blurred; biogeographical delimitation works with arbitrarily defined regions to which species are traditionally assigned as native or alien, and the definition of an alien is bound to introduction and dispersal resulting from human activities (Richardson et al. 2000; Blackburn et al. 2011). However, at the ecological scale, the application of the principle "the species would not be present had not been for the activities of humans" (Pyšek et al. 2004) becomes more vague. When classifying species as alien, authors generally do not consider the effect of landuse changes and global environmental change on the spread of native species through landscapes transformed by human activities (Chytrý et al. 2012). Such species would not be present in some of their locales without the influence of humans either, but are 
considered native to the region as a whole, mostly due to lack of information needed to make such distinctions. This can be illustrated for the British Isles; the New Atlas of the British and Irish Flora (Preston et al. 2002) is probably the only available source that distinguishes between native and alien occurrences of species that are native to the British Isles as a whole, thereby consistently applying the principles normally used at the biogeographical scale to an ecological grain of study. Using such information reveals species that are good dispersers in their native geographical range and are not confined to their native habitats, exhibiting thus potential to spread (Fig. 1).

\section{Our results are only as good as our data}

As pointed by Guo (2011), not distinguishing between the two groups according to origin (or ignoring the "internal" introductions) can have serious consequences for management since these species impact on ecosystems in the same way as "true exotics". Some continental-scale analyses of invasive species impacts indeed restrict the assessment to invasive species originating from overseas (e.g., Nentwig et al. 2009; Kumschick et al. 2011; but see Vilà et al. 2011) and data to separate the effects of both origin-based groups are not available. There is however one piece of evidence from the United States. Paini et al. (2010) showed that immediate present-day threat from known invasive insect pests is greater from within the United States than from the outside and advocate for invasive species policy paying increased awareness of state-level post-border biosecurity.

In terms of science, lumping both groups of origin together may obscure ecological analyses since the groups differ in many respects; the data gathered for Europe again allow for a more detailed insight. Besides the fact that biased species richness complicates comparisons between regions for which the data was collected by one approach or the other (Guo 2011), there are differences in historical dynamics and rates of introduction. Aliens of European origin for example tended to start spreading earlier in Europe than those from overseas(Lambdon et al. 2008). Similarly, comparison of the alien flora of California from different time periods shows that species of within-continental origin increased their percentage contribution over the period of 50 years from about 8 to 15\% (Rejmánek and Randall 1994). European data further show that both groups differ in terms of distribution (almost all among the 15 most widely distributed species in terms of the number of region have their native ranges outside Europe), taxonomy (only a few large genera which have successfully invaded are predominantly non-European), hybridization rate (European natives hybridize more frequently) or habitat affiliation (aliens of European origin tend to occur in a wider range of habitats, most likely profitting from a better habitat match and longer residence times) (Lambdon et al. 2008; Pyšek et al. 2009b).

Moreover, comparisons seeking for determinants of regional invasibility based on floras of whole states or groups of states can be misleading. This is because high environmental heterogeneity across a large area may hide the patterns that could be seen if comparing alien species richness within smaller, more homogeneous areas that are more 


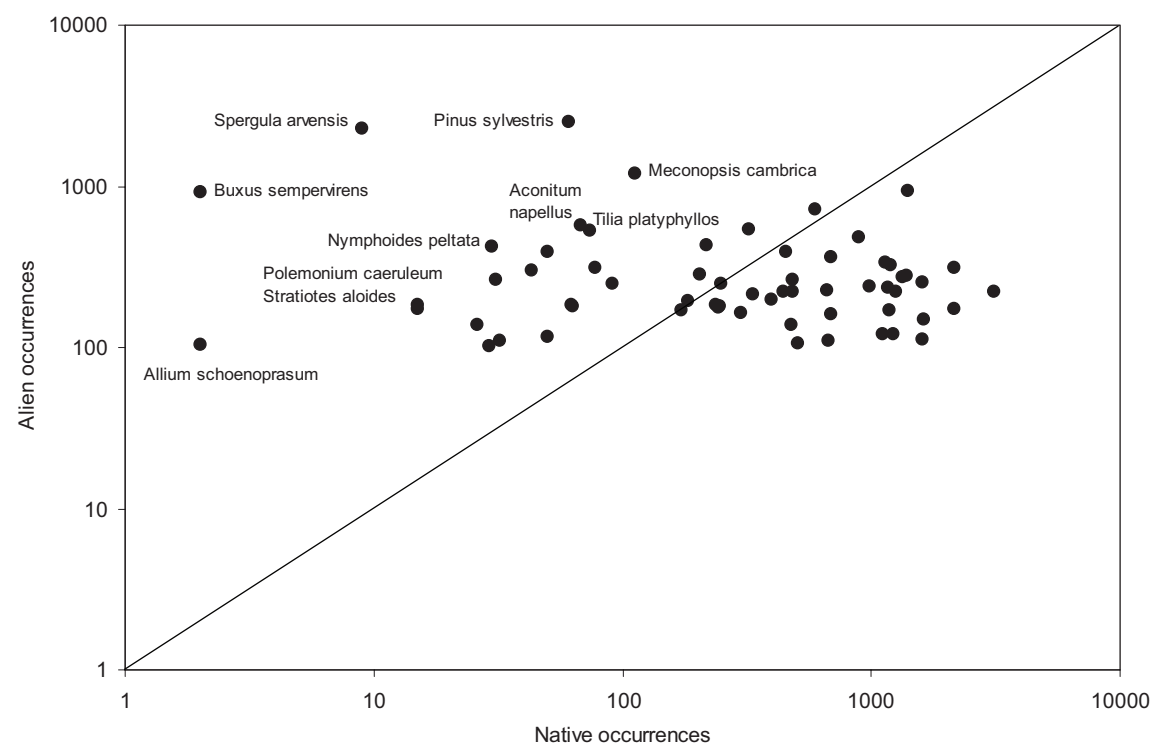

Figure I. Number of $10 \times 10 \mathrm{~km}$ grid cells in which species native to the British Isles, that also occur in localities where their occurrence is considered alien, were mapped in 1987-1999. Species above and below the unity line are recorded more frequently as "aliens" and "natives", respectively. Based on data from Preston et al. (2002), using species with at least 100 "alien" occurrences and excluding hybrids. For species in the top left part of the plot, more than $90 \%$ of records refer to alien occurrences, those with the greatest disproportions towards the "alien" occurrences are labelled. Note the log scale.

suitable for revealing causal connections between environmental factors, anthropic disturbance, history, and numbers of alien species (Rejmánek and Randall 1994).

In invasion biology, it is becoming increasingly important to synthesize existing data on alien species abundances and distributions (Crall et al. 2006; Richardson and Pyšek 2006; Pyšek et al. 2009a, 2010; Stohlgren et al. 2011). The important issue raised by Guo (2011) points to that in invasion biology, a field currently enjoying intensive research but relying heavily, for theory, on data collected in different parts of the world by varying means and approaches, it is essential that assumptions of each study are clearly defined and stated. Our results are only as good as our data, and comparability of results drawn from different regions is a necessary step towards building a general framework and synthesis of the field.

\section{Acknowledgments}

The author was supported by long-term institutional research plans no. AV0Z60050516 (Academy of Sciences of the Czech Republic), no. MSM0021620828 (Ministry of Education of the Czech Republic), and by the Praemium Academiae award from the Academy of Sciences of the Czech Republic. 


\section{References}

Blackburn TM, Pyšek P, Bacher S, Carlton JT, Duncan RP, Jarošík V, Wilson JRU, Richardson DM (2011) A proposed unified framework for biological invasions. Trends in Ecology and Evolution 26: 333-339. doi: 10.1016/j.tree.2011.03.023

Chytrý M, Wild J, Pyšek P, Jarošík V, Dendoncker N, Reginster I, Pino J, Maskell L, Vilà M, Pergl J, Kühn I, Spangenberg J, Settele J (2012) Projecting trends in plant invasions in Europe under different scenarios of future land-use change. Global Ecology and Biogeography, in press. doi: 10.1111/j.1466-8238.2010.00573.x

Crall AW, Meyerson LA, Stohlgren TJ, Jarnevich CS, Newman GJ, Graham J (2006) Show me the numbers: what data currently exist for non-native species in the USA? Frontiers in Ecology and the Environment 4: 414-418. doi: 10.1890/1540-9295(2006)4[414:SMTN WD]2.0.CO;2

DAISIE (2009) Handbook of Alien Species in Europe. Springer, Berlin.

Guo Q (2011) Counting “exotics”. Neobiota 9: 71-73.

Hamilton MA, Murray BR, Cadotte MW, Hose GC, Baker AC, Harris CJ, Licari D (2005) Life-history correlates of plant invasiveness at regional and continental scales. Ecology Letters 8: 1066-1074. doi: 10.1111/j.1461-0248.2005.00809.x

Hickman JC (Ed) (1993) The Jepson Manual. University of California Press, Berkeley.

Kumschick S, Alba C, Hufbauer RA, Nentwig W (2011) Weak or strong invaders? A comparison of impact between the native and invaded ranges of mammals and birds alien to Europe. Diversity and Distributions 17: 663-672. doi: 10.1111/j.1472-4642.2011.00775.x

Lambdon PW, Pyšek P, Basnou C, Hejda M, Arianoutsou M, Essl F, Jarošík V, Pergl J, Winter M, Anastasiu P, Andriopoulos P, Bazos I, Brundu G, Celesti-Grapow L, Chassot P, Delipetrou P, Josefsson M, Kark S, Klotz S, Kokkoris Y, Kühn I, Marchante H, Perglová I, Pino J, Vilà M, Zikos A, Roy D, Hulme PE (2008) Alien flora of Europe: species diversity, temporal trends, geographical patterns and research needs. Preslia 80: 101-149.

Nentwig W, Kühnel E, Bacher S (2009) A generic impact-scoring system applied to alien mammals in Europe. Conservation Biology 24: 302-311. doi: 10.1111/j.15231739.2009.01289.x

Paini DR, Worner SP, Cook DC, De Barro PJ, Thomas MB (2010) Threat of invasive pests from within national borders. Nature Communications 1: 115. doi: 10.1038/ncomms1118

Palmer MW (2005) Temporal trends of exotic species richness in North American floras: an overview. Ecoscience 12: 386-390. doi: 10.2980/i1195-6860-12-3-386.1

Preston CD, Pearman DA, Dines TD (2002) New Atlas of the British and Irish Flora. Oxford University Press, Oxford.

Pyšek P (2003) How reliable are data on alien species in Flora Europaea? Flora 198: 499-507. doi: 10.1078/0367-2530-00122

Pyšek P, Hulme PE (2005) Spatio-temporal dynamics of plant invasions: linking pattern to process. Ecoscience 12: 302-315. doi: 10.2980/i1195-6860-12-3-302.1

Pyšek P, Jarošík V, Hulme PE, Kühn I, Wild J, Arianoutsou M, Bacher S, Chiron F, Didžiulis V, Essl F, Genovesi P, Gherardi F, Hejda M, Kark S, Lambdon PW, Desprez-Loustau AM, 
Nentwig W, Pergl J, Poboljšaj K, Rabitsch W, Roques A, Roy DB, Shirley S, Solarz W, Vilà M, Winter M (2010) Disentangling the role of environmental and human pressures on biological invasions across Europe. Proceedings of the National Academy of Sciences of the United States of America 107: 12157-12162. doi: 10.1073/pnas.1002314107

Pyšek P, Jarošík V, Pergl J, Randall R, Chytrý M, Kühn I, Tichý L, Danihelka J, Chrtek J jun, Sádlo J (2009a) The global invasion success of Central European plants is related to distribution characteristics in their native range and species traits. Diversity and Distributions 15: 891-903. doi: 10.1111/j.1472-4642.2009.00602.x

Pyšek P, Lambdon P, Arianoutsou M, Kühn I, Pino J, Winter M (2009b) Alien vascular plants of Europe. In: DAISIE (Eds) Handbook of Alien Species in Europe. Springer, Berlin, 43-61. Pyšek P, Richardson DM, Pergl J, Jarošík V, Sixtová Z, Weber E (2008) Geographical and taxonomic biases in invasion ecology. Trends in Ecology and Evolution 23: 237-244. doi: 10.1016/j.tree.2008.02.002

Pyšek P, Richardson DM, Rejmánek M, Webster G, Williamson M, Kirschner J (2004) Alien plants in checklists and floras: towards better communication between taxonomists and ecologists. Taxon 53: 131-143. doi: 10.2307/4135498

Pyšek P, Sádlo J, Mandák B (2002) Catalogue of alien plants of the Czech Republic. Preslia 74: 97-186.

Rejmánek M (2000) Invasive plants: approaches and predictions. Austral Ecology 25: 497506. doi: 10.1046/j.1442-9993.2000.01080.x

Rejmánek M, Randall R (1994) Invasive alien plants in California: 1993 summary and comparison with other areas in North America. Madrono 41: 161-177.

Rejmánek M, Thomsen CD, Peters ID (1991) Invasive vascular plants of California. In: Groves RH, di Castri F (Eds) Biogeography of Mediterranean Invasions. Cambridge University Press, Cambridge, 81-101.

Richardson DM, Pyšek P (2006) Plant invasions: merging the concepts of species invasiveness and community invasibility. Progress in Physical Geography 30: 409-431. doi: 10.1191/0309133306pp490pr

Richardson DM, Pyšek P, Rejmánek M, Barbour MG, Panetta FD, West CJ (2000) Naturalization and invasion of alien plants: concepts and definitions. Diversity and Distributions 6: 93-107. doi: 10.1046/j.1472-4642.2000.00083.x

Stohlgren TJ, Pyšek P, Kartesz J, Nishino M, Pauchard A, Winter M, Pino J, Richardson DM, Wilson JRU, Murray BR, Phillips ML, Ming-yang L, Celesti-Grapow L, Font X (2011) Widespread plant species: natives versus aliens in our changing world. Biological Invasions 13: 1931-1944. doi: 10.1007/s10530-011-0024-9

Vilà M, Espinar JL, Hejda M, Hulme PE, Jarošík V, Maron JL, Pergl J, Schaffner U, Sun Y, Pyšek P (2011) Ecological impacts of invasive alien plants: a meta-analysis of their effects on species, communities and ecosystems. Ecology Letters 14: 702-708. doi: 10.1111/j.14610248.2011.01628.x

Weber EF (1997) The alien flora of Europe: a taxonomic and biogeographic overview. Journal of Vegetation Science 8: 565-572. doi: 10.2307/3237208 
Winter M, Schweiger O, Klotz S, Nentwig W, Andriopoulos P, Arianoutsou M, Basnou C, Delipetrou P, Didžiulis V, Hejda M, Hulme PE, Lambdon PW, Pergl J, Pyšek P, Roy DB, Kühn I (2009) Plant extinctions and introductions lead to phylogenetic and taxonomic homogenization of the European flora. Proceedings of the National Academy of Sciences of the United States of America 106: 21721-21725. doi: 10.1073/pnas.0907088106 